2003-01-01

Problems facing maerl conservation in Brittany

Grall, J

http://hdl.handle.net/10026.1/1359

10.1002/aqc.568

Aquatic Conservation-Marine and Freshwater Ecosystems

Wiley

All content in PEARL is protected by copyright law. Author manuscripts are made available in accordance with publisher policies. Please cite only the published version using the details provided on the item record or document. In the absence of an open licence (e.g. Creative Commons), permissions for further reuse of content should be sought from the publisher or author. 


\title{
Problems facing maerl conservation in Brittany
}

\author{
J. GRALL ${ }^{\mathrm{a}, *}$ and J.M. HALL-SPENCER ${ }^{\mathrm{b}}$ \\ ${ }^{a}$ Institut Universitaire Européen de la Mer, LEMAR UMR-CNRS 6539, Place Copernic, 29280, Plouzane, Brittany, \\ France \\ ${ }^{\mathrm{b}}$ School of Biological Sciences, University of Plymouth, Drake Circus, Plymouth, PL4 8AA, UK
}

\begin{abstract}
1. Brittany has the majority of French maerl beds and some of the most extensive maerl grounds in Europe.

2. Breton maerl forms ancient ( $>5500 \mathrm{yr}$ ) but threatened habitats; several beds have been destroyed in the past 30 years.

3. Maerl extraction, eutrophication, mariculture and fishing are all major threats to Breton maerl beds, as is a continuing uncontrolled spread of the invasive gastropod Crepidula fornicata.

4. Maerl beds occur in 14 of the 28 Natura 2000 sites proposed along the Breton coast.

5. Maerl habitats are currently impacted by human activities in nearly all of the Breton proposed Natura 2000 sites which were mainly selected for terrestrial nature conservation features.

Copyright (C) 2003 John Wiley \& Sons, Ltd.
\end{abstract}

KEY WORDS: maerl, Brittany, extraction, invasive species, eutrophication, dredging, Natura 2000

\section{INTRODUCTION}

'Maerl' is a Breton word (Lemoine, 1910) used to describe live and dead accumulations of unattached coralline algae. Extensive taxonomic research by Cabioch $(1966,1969,1970)$ has established that the main maerl-forming species in Brittany are Lithothamnion corallioides (P and H Crouan) $\mathrm{P}$ and H Crouan and Phymatolithon calcareum (Pallas) Adey and McKibben, although other species are present in small amounts. Maerl-forming species grow under a restricted range of conditions (Birkett et al., 1998; Hall-Spencer et al., 2003; BIOMAERL team, 2003) such that they are patchily distributed along the Breton coast (Cabioch, 1969; Gautier, 1971). They can occur in sheltered and exposed waters, however, and form accumulations that cover several $\mathrm{km}^{2}$ (e.g. $20 \mathrm{~km}^{2}$ in the Bay of Brest). The Glenan islands in SW Brittany have the thickest known maerl deposits in the world, with accumulations up to $10 \mathrm{~m}$ thick reported by Augris and Berthou (1986). Although maerl has a sporadic distribution along the Mediterranean

*Correspondence to : J. Grall, Institut Universitaire Européen de la Mer, LEMAR UMR-CNRS 6539, Place Copernic, 29280, Plouzane, Britanny, France. E-mail: jgrall@univ-brest.fr 
(Jacquotte, 1962; Bellan-Santini et al., 1994) and Atlantic/Channel coasts of France the main national maerl resource is concentrated in Brittany (Augris and Berthou, 1990).

French maerl deposits have a long history of research (Paturel, 1898; Lemoine, 1910; Hamel and Lemoine, 1953). Biotope mapping in the 1960s-70s (Cabioch, 1968; Glémarec, 1969; Retière, 1979) provided detailed descriptions of Breton maerl bed communities and distinguished them from other types of gravel shown on sedimentary maps of the area (Boillot, 1964; Hinschberger, 1968). Throughout the study of Breton grounds, researchers have emphasized the high biodiversity of maerl compared with other sublittoral sediments. More recently this has led to calls for their conservation (Dauvin, 1997; BIOMAERL, 1999). The total number of Breton maerl beds has not yet been assessed since they can be small $\left(10-100 \mathrm{~m}^{2}\right)$ and are therefore difficult to map. However, Gautier (1971) recorded at least 70 maerl beds $>1 \mathrm{~km}^{2}$ from around 17 bays and archipelagoes in the region.

Celtic peoples have used calcareous marine sediments to enrich soils for centuries. In 79 AD, Pliny noted that 'in Britain and Gaul, people had invented an art to fertilize their soils, by means of a certain soil (Marga)'. Augris and Berthou (1990) note that this 'Marga' could have come from raised calcareous beaches (called 'marne' in French) or sublittoral deposits of coralline algae (called 'marl' or 'maerl' in Breton). Maerl extraction increased dramatically in the second half of the 20th century with the use of motorized vessels and peaked at $c a 600000 \mathrm{t} \mathrm{yr}^{-1}$ in the 1970s (Augris and Berthou, 1990). Today, Breton maerl is extracted at $c a 500000 \mathrm{t} \mathrm{y}^{-1}$ and used in a variety of industrial processes including agriculture, water purification, mineralization and the manufacture of cosmetics (Briand, 1989; Augris and Berthou, 1990). The ancient tradition of maerl extraction was probably the first way in which humans impinged upon the ecology of Breton maerl beds. Large-scale maerl extraction over the past 30 years has removed and degraded these habitats. Other major impacts on local maerl bed habitats include the spread of the invasive gastropod Crepidula fornicata, industrial and urban sewage, aquaculture and demersal fishing. These impacts have increased sharply since the 1970s and are causing widespread damage to Breton maerl beds. The European Commission's Natura 2000 initiative has been used in France to highlight maerl beds as vulnerable, high biodiversity habitats that are in need of protection and management. A substantial number of Breton maerl beds have recently been included in the proposed marine Special Areas of Conservation for Natura 2000, yet little is known of the present status or vulnerability to threats of these habitats. In this paper we discuss the known distribution of major Breton maerl beds and provide an overview of current threats to these habitats in relation to the proposed French Natura 2000 sites.

\section{Maerl Extraction}

Many of the largest (several $\mathrm{km}^{2}$ ) and thickest (7-10 $\mathrm{m}$ ) Breton maerl beds are currently actively exploited. Extraction results in maerl habitat removal with severe impacts on its associated biota (Augris and Berthou, 1986; Grall and Glémarec, 1997a; BIOMAERL, 1999). During extraction, the maerl is washed at sea releasing fine particles that settle and smother the surrounding habitat (Figure 1). This kills live maerl and alters maerl-associated communities over a much wider area than that directly affected by extraction (DeGrave and Whitaker, 1999). One of the largest maerl beds in Brittany is the Glenan deposit with an estimated 12 million $\mathrm{m}^{3}$ of maerl (Augris and Berthou, 1986). This maerl bed is well documented historically (Lemoine, 1910; Glémarec, 1969; Pinot, 1974; Blunden et al., 1977; BIOMAERL, 1999) and was covered in living maerl until maerl extraction started $35 \mathrm{yr}$ ago (Pinot, in Dauvin, 1997). A more recent survey in 1999 found that live maerl was very rare over most of this bank and no macrofauna were observed in grab and core samples taken in the extraction zone (BIOMAERL, 1999). Sub-samples of maerl from these grab samples were submitted for radiocarbon dating; two samples were prepared to graphite at the NERC laboratory in East Kilbride, Scotland, and sent to the Center for Accelerator Mass Spectrometry, Lawrence Livermore National Laboratory, University of California for ${ }^{14} \mathrm{C}$ analysis. The surface maerl thalli (code CAMS-70059) had a conventional radiocarbon age of $1190+/-40$ years $\mathrm{BP}$ (relative to AD 


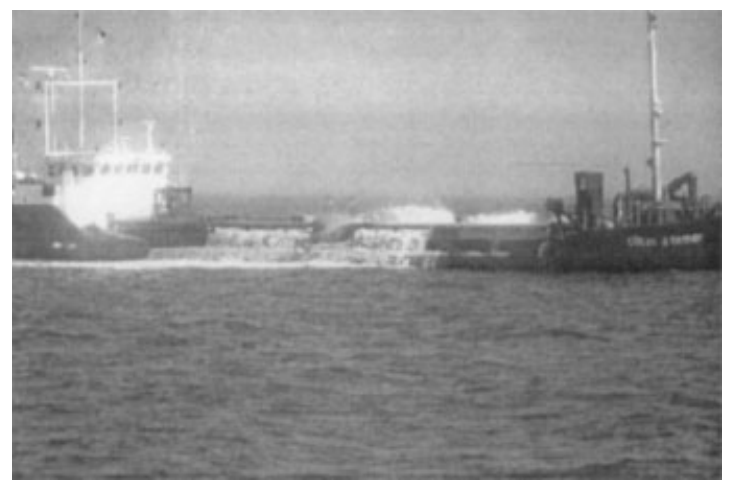

Figure 1. The Côtes d'Armor; a maerl extraction dredger in use on the Glenan maerl banks in SW Brittany, June 1997. Note the suspended sediment that is washed overboard.

1950) and $86.22+/-0.39$ modern ${ }^{14} \mathrm{C}$ enrichment. The subsurface thalli (code AA-49821) had a conventional radiocarbon age of $5862+/-57$ years BP and $48.2+/-0.34$ modern ${ }^{14} \mathrm{C}$ enrichment (errors all $+/-1 \sigma$ level for overall analytical confidence). Thus the $10 \mathrm{~m}$ thick Glenan maerl bank has been slowly accumulating over much of the Holocene.

A comparison of faunal surveys of the Glenan maerl bank by Glémarec (1969) with surveys in 1999 reveals a shift from a diverse community typical of Breton maerl beds (Cabioch, 1968) to an impoverished muddy-sand community (BIOMAERL, 1999). The biotope was previously described as clean maerl gravel with low silt ( $2 \%$ fines; <63 $\mu \mathrm{m}$ grain size) and abundant suspension-feeding bivalves (Glémarec, 1969) but is now a muddy sand ( $15 \%$ fines) dominated by deposit feeders and omnivores. Similar community changes have been described at a maerl extraction site in Ireland (DeGrave and Whitaker, 1999). Thus within 30 years, most of the Glenan maerl habitat has been degraded, leaving a species-poor muddy sand community. More than $200 \mathrm{t} \mathrm{yr}^{-1}$ of bivalves (e.g. Pecten maximus, Tapes rhomboides) are fished from the Glenan bank (Augris and Berthou, 1990) which has led to conflicts of interest between fishermen and maerl bed extractors. Hall-Spencer et al. (2003) discuss the potential benefits of maerl bed protection for enhancing the productivity of bivalve fisheries.

Pinot (in Dauvin, 1997) calculated that annual rates of extraction from the Glenan bank were five times higher than the natural rate of renewal $(90000$ metric tons versus 14000 metric tons of potential production). However, this calculation assumed that the bank is covered in a living veneer of live maerl thalli. In fact, maerl is essentially a non-renewable resource (BIOMAERL, 1999); living maerl has been killed over most of the Glenan bank and thus present-day production is negligible. If extraction rates remain at current levels, we estimate that the Glenan bed will be completely removed in 50-100 years. Augris and Berthou (1990) found that several Breton maerl beds were smaller than indicated on early charts of the area whilst Pinot (in Dauvin, 1997) noted that at least four maerl beds have been destroyed by extraction in Brittany (Figure 2).

Table 1 lists the Natura 2000 sites that include maerl and shows that only one of the proposed areas (FR53/20) has relatively pristine maerl. It is important to note that maerl was not given priority in the selection of these Natura 2000 sites; their choice was based largely upon terrestrial conservation interests adjacent to the sea. Thus three of the most intensively dredged maerl beds (Erquy, Paimpol, Glenan) are within Natura 2000 sites, these three sites account for $80 \%$ of the total $500000 \mathrm{t}$ extracted annually in Brittany and represent the largest maerl resource in France (Augris and Berthou, 1990). The maerl extraction industry provides hundreds of local jobs (Briand, 1989) which could be maintained if the industry moves to exploit maerl substitutes such as calcareous marine sands or the crushed dead shells of exploited bivalves and invasive species (Pinot in Dauvin, 1997). The Glenan archipelago is also a terrestrial 


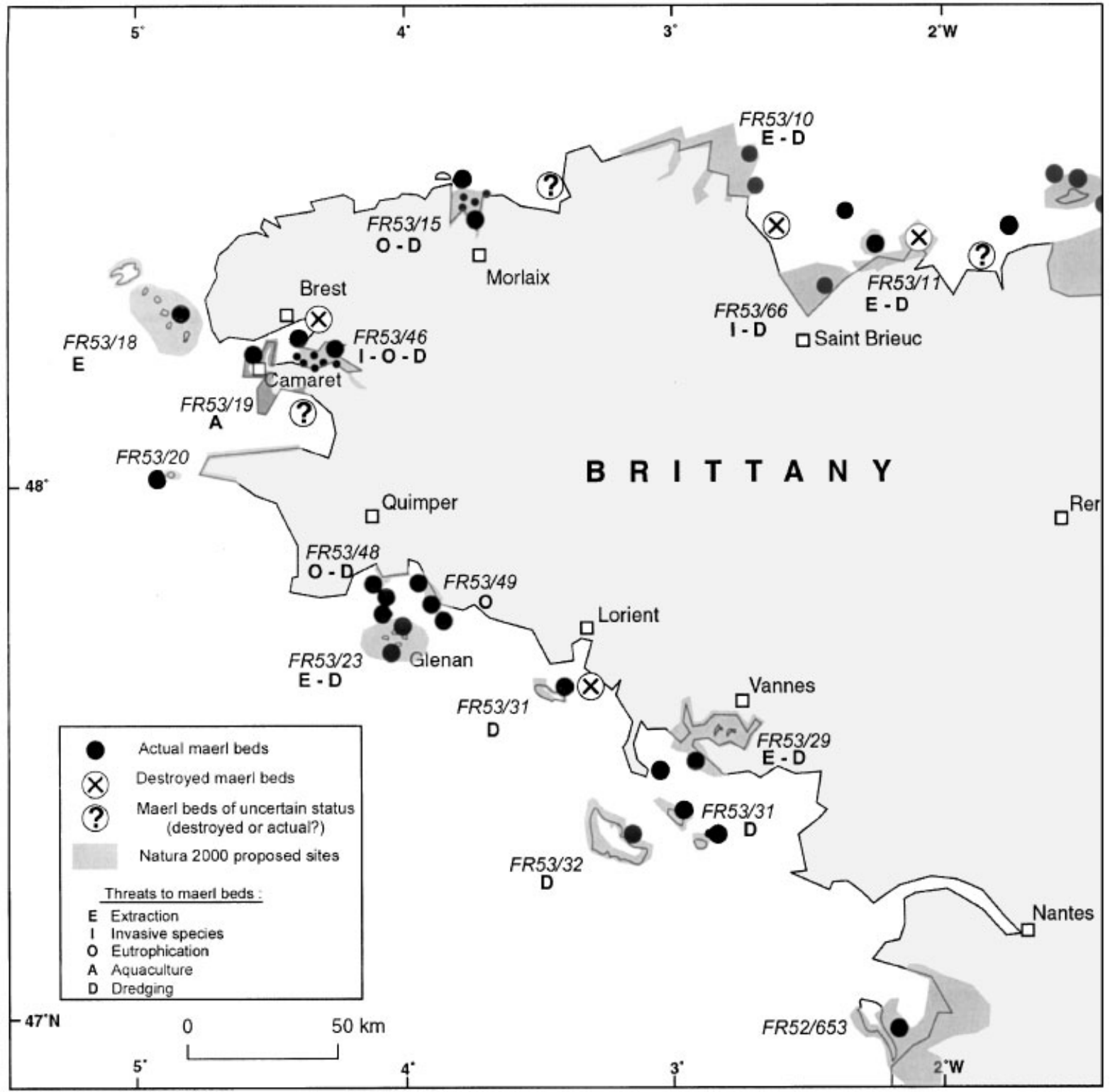

Figure 2. Map showing the location of maerl beds in Brittany, their present status and potential threats in relation to the Natura 2000 proposed sites. Site codes are taken from the French government website (2002) listing proposed conservation areas under the Natura 2000 initiative. Natura sites marked on are onshore as well as coastal : in Brittany all coastal Natura 2000 proposed sites include onshore and intertidal and subtidal habitats, down to 20 metres. On the map the complete Natura 2000 sites delimitation are given (i.e. including onshore delimitation). Except for site FR 53/49 (Trevignon), maerl beds were not taken into account for the proposition of the sites.

nature reserve that is regionally important for tourism and nationally important for rare plants such as the Glenan Daffodil (Narcissus triandus, Bioret and Malengrau, 1989). The reserve warden, Frédéric Bioret, has reported significant erosion of maerl beaches over the last decade. It is possible that the annual removal of $90000 \mathrm{~m}^{3}$ of maerl from the offshore banks has contributed to this erosion, given that maerl replenishes 
Table 1. Different impacts on the Breton coastal Natura 2000 sites including maerl beds. Only proposed site FR53/20 (Ile de Sein) is not under the influence of any of these impacts

\begin{tabular}{|c|c|c|c|c|c|}
\hline Site code - Name & Extraction & Fishing (dredge) & Invasive species & Eutrophication & Aquaculture \\
\hline FR 53/11 - Caps d'Erquy—Frehel & $\boldsymbol{\nu}$ & $\boldsymbol{\nu}$ & & & \\
\hline FR 53/66 — Baie de Saint Brieuc & & $\boldsymbol{}$ & $\boldsymbol{\nu}$ & & \\
\hline FR 53/10 - Brehat, Jaudy, Trieux & $\boldsymbol{}$ & レ & & & \\
\hline FR 53/15 - Baie de Morlaix & & $\boldsymbol{\nu}$ & & $\boldsymbol{\nu}$ & \\
\hline FR 53/18 - Archipel de Molène & レ & & & & \\
\hline FR 53/46 — Rade de Brest & & レ & レ & $\boldsymbol{}$ & \\
\hline FR 53/19 - Baie de Camaret & & $\boldsymbol{\nu}$ & & & レ \\
\hline FR $53 / 48$ - Mousterlin & & $\boldsymbol{\nu}$ & & $\boldsymbol{\nu}$ & \\
\hline FR 53/49 - Trevignon & & & & レ & \\
\hline FR 53/23 - Archipel des Glenan & レ & $\boldsymbol{\nu}$ & & & \\
\hline FR 53/31 - Ile de Groix & & $\boldsymbol{\nu}$ & & & \\
\hline FR 53/29 - Golfe du Morbihan & レ & レ & & & \\
\hline FR 53/31 - Houat, Hoedic & & $\boldsymbol{\nu}$ & & & \\
\hline FR 53/32 - Belle Ile en Mer & & 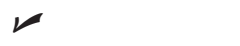 & & & \\
\hline
\end{tabular}

beaches and protects them from westerly swells in the region (Pinot in Dauvin, 1997). Erosion of some of the finest beaches in Brittany is of serious concern both for nature conservation and the tourist industry, although this has not been taken into account in environmental assessments of maerl extraction activities.

\section{Invasive species}

The slipper limpet Crepidula fornicata was accidentally introduced to France sometime between the 1940s - 60s along with oysters for aquaculture. This calyptraeid gastropod has since spread along the whole Channel-Atlantic coast of France (De Montaudouin et al., 1999). In shallow bays, it can completely smother the sediment creating beds with several thousand individuals per $\mathrm{m}^{2}$ (Figure 3). Thouzeau et al. (2000) described Crepidula grounds as a separate biotope with its own characteristic community. Dense aggregations of $C$. fornicata trap suspended silt, faeces and pseudofaeces which alter the specific composition and structure of benthos (Chauvaud et al., 2000). Live maerl thalli become covered in Crepidula and the interstices of the deposit become clogged with silt; this kills the maerl thalli and

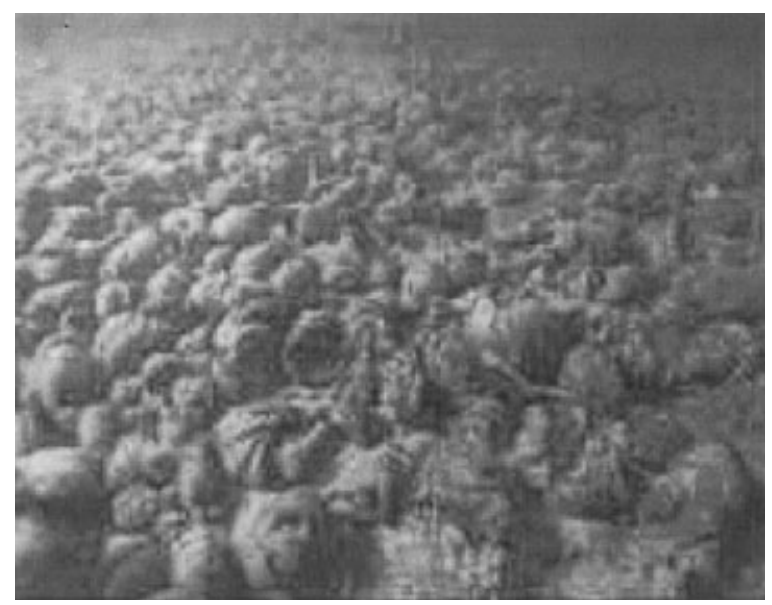

Figure 3. Crepidula fornicata overgrowing maerl in the Bay of Brest. Photograph by E. Amice, Lemar IUEM. 
dramatically alters associated maerl communities. In the Bay of Saint-Brieuc, Thouzeau (1989) found that the highest densities of Crepidula (400 individuals per $\mathrm{m}^{2}$ ) occurred on the local maerl beds. More recent surveys indicate that maerl covering an area of $4 \mathrm{~km}^{2}$ has subsequently been smothered under a proliferation of calyptreid gastropods (Hamon and Blanchard, 1994). Bivalve dredging is no longer possible on this bank because the dredges become clogged with Crepidula and the scallop population densities are much lower on Crepidula beds than on maerl grounds (Thouzeau et al., 2000).

Two of the proposed Natura 2000 sites for Brittany have maerl that is impacted by Crepidula (Table 1). In the Bay of Brest, C. fornicata is now the main suspension feeder in the ecosystem (Chauvaud et al., 2000) and the area covered by the species increased from $45 \mathrm{~km}^{2}$ in 1978 (Coum, 1979) to $90 \mathrm{~km}^{2}$ in 1995. Although maerl beds have generally low levels of Crepidula infestation (maximum densities reaching 100 individuals per $\mathrm{m}^{2}$ ), some of them are surrounded by the most dense Crepidula beds in the bay and may soon be smothered (Chauvaud et al., 2000). Programmes of Crepidula removal/eradication by dredging were initiated in 2002 (Ifremer website, 2002). However, this involves removal of the surface layer of sediment and may impact maerl habitats more severely than proliferation of the gastropod itself since removal of live maerl cover results in long-term habitat damage (Pinot in Dauvin, 1997; Hall-Spencer and Moore, 2000). Unlike the threat from commercial extraction outlined above, the proliferation of Crepidula is an insidious threat to maerl habitats for which we have no obvious solution.

\section{Fishing}

High densities of edible bivalves often occur on Breton maerl beds and most are dredged for scallops and clams (Pecten maximus, Chlamys varia, Aequipecten opercularis, Tapes rhomboides, Venus verrucosa, Spisula subtruncata). Table 1 shows that most of the Natura 2000 sites proposed for Brittany have maerl beds that are fished with towed gear. Hall-Spencer and Moore (2000) showed that bivalve dredging has long-term impacts on maerl communities as it kills the surface layer of living thalli upon which the habitat depends. Although many of the species associated with maerl communities are small or burrow deeply enough to survive the passage of fishing gear, dredging reduces the biodiversity and structural complexity of the maerl. Fishing on Breton maerl beds is widespread (Augris and Berthou, 1990; Table 1) yet there are tangible economic benefits to be gained from protecting selected maerl grounds as feeding areas for juvenile fish or to preserve brood stocks of commercial bivalve species (Hall-Spencer et al., 2003).

\section{Eutrophication, organic matter input}

Numerous Breton maerl beds are currently influenced by sewage outfalls including four sites within the proposed Natura 2000 network (Table 1). Grall and Glémarec (1997a,b) described the effects of urban and industrial waste on maerl and other benthic communities in the Bay of Brest which is strongly influenced by agricultural, urban sewage and industrial waste. Water pollution in the northern basin comes mainly from urban stormwater discharge and sewer outflows and has led to increased levels of heavy metals, hydrocarbons, suspended solids, microbes and organic matter together with an increase in oxygen demand in the surrounding sediments (Huet et al., 1995; Patris et al., 1995). The main consequences of such pollution on maerl beds are similar to those described for other types of sedimentary habitat (Pearson and Rosenberg, 1978; Weston, 1990; Gray, 1992). There is an increase in siltation and a higher abundance and biomass of opportunistic species which replace sensitive species. There are decreases in functional and species diversity together with a reduction in the thickness of live maerl cover (Grall and Glémarec, 1997a).

Two maerl beds have been killed in the Bay of Brest, both of which were situated directly under sewage outflows. These were studied fifty years ago by Berthois and Guilcher (1959) who described dense deposits of live maerl covering sandy mud mixed with dead maerl. Today these areas are made up of heterogeneous mud with maerl fragments buried under several centimetres of fine sediment with species-poor communities that are dominated by opportunists (Grall and Glémarec, 1997a). A large maerl bank $\left(3 \mathrm{~km}^{2}\right)$, situated 
further south is under the influence of the city sewage where monitoring over the past 10 years has shown a steady increase in siltation and opportunistic species and a decrease in overall species diversity (Grall and Glémarec, 1997a,b). If there are no improvements to local waste water treatment this maerl bed is also likely to be destroyed.

Where maerl thalli survive eutrophication and sewage inputs, the functional and species diversity of the associated biota is changed radically. The resultant communities are quite dissimilar from those that occur on clean maerl grounds (e.g. Cabioch, 1968; Glémarec, 1969). Unlike extraction or bivalve fishing, which provide employment, no such socioeconomic benefits accrue from poor sewage treatment (Patris et al., 1995). We recommend that improvements be made to water quality prior to discharge and that outlets be positioned to avoid direct influence of sewage on Breton maerl beds.

\section{Impact of aquaculture}

Aquaculture can impact maerl habitats through deposition of organic material (Judas, 1998). Mussel farming has impacted maerl habitats in Spain (BIOMAERL, 1999), but as yet mussel farms are not sited above Breton maerl beds. Fish farms, however, are sited on local maerl beds (Table 1) and pollute the benthos below cages. In 1997, sea trout cages were sited above maerl in the Bay of Camaret. Six months after installation an impact survey was carried out taking samples below the cages and at a control site on maerl away from the influence of the farm (Judas, 1998). This study revealed degradation of the benthic environment under the cages, similar to that described by Drake and Arias (1997). Siltation and organic content were higher in sediments under the cages where the community had a lower biodiversity and a greater abundance of opportunistic species (e.g. Capitella capitata complex, Chaetozone setosa). Fish bones, faecal pellets and fish food granules were found in the maerl matrix, enriching the sediment in organic matter. Repeat surveys have not been made, but the cages have now been in place for 5 years so that the build-up of organic waste is likely. We propose that future mariculture installations are sited carefully, particularly within Natura 2000 sites, to avoid unneccessary damage to sensitive types of benthic habitat.

\section{CONCLUSIONS}

Brittany remains a 'hot-spot' for maerl beds. It has some of the largest examples in Europe which have high conservation interest - they have an outstanding biological diversity and provide the carbonate sands for beautiful white beaches. However, these ancient ( $>5500$ year old) biogenic habitats are fragile and have been severely degraded especially over the past 30 years. Although maerl is listed on Annex V of EC Habitats Directive, requiring an appropriate management plan for extraction or exploitation, France has the largest maerl extraction scheme in the world. Maerl extraction in Brittany is now under the control of the French mining management scheme, with quota schemes (80 000 metric tons in 2001 on the Glenan bank) and regular environmental surveys. However, such quotas are not compatible with regeneration of the resource - the situation is akin to harvesting peat on land where removal far outstrips production.

Most Breton maerl beds are affected by human activities, leading to heated conflicts between competing users (e.g. extractors vs fishermen). The only pristine grounds remaining are small (therefore unattractive to extractors) and occur outside polluted inshore waters in rocky areas that cannot be fished with towed demersal gear. These small grounds are a poor reflection of the extensive (several $\mathrm{km}^{2}$ ) maerl beds that inspired marine biologists in the 1960s (Cabioch, 1966, 1968, 1969, 1970;Glemarec, 1969). Today, at least seven extensive (several $\mathrm{km}^{2}$ ) maerl grounds have been extracted, buried or affected by the spread of Crepidula fornicata. Such declines in one of the most diverse habitats of European waters (BIOMAERL, 1999) have not previously been reported and emphasize the urgent need for maerl bed conservation in France and Europe. The west coasts of Norway, Scotland and Ireland provide similar 'hot-spots' for maerl 
(Birkett et al., 1998; BIOMAERL, 1999) where active conservation policies are essential if the Breton experience is to be avoided.

Of the 28 coastal Natura 2000 sites proposed along the Breton coast, 14 contain maerl beds (Figure 2). However, only one of these maerl beds does not suffer any of the threats listed above (Ile de Sein, site code FR53/49). Several of the proposed Natura 2000 sites include maerl beds that are subject to a suite of human impacts. Maerl in the Bay of Brest, for example, is affected by dredge fishing, eutrophication and the spread of Crepidula fornicata. If the people of Brittany are to benefit from maerl in the future (e.g. as brood stock and feeding areas for commercial fish and to protect beaches for tourism) then action is needed now.

The problems facing maerl bed conservation in France are many with impacts ranging from large-scale extraction, fishing, aquaculture and sewage pollution. The Natura 2000 scheme is a good starting point and needs to be harnessed in combination with a raised awareness of the vulnerability of local maerl habitats. Future developments, particularly in Natura 2000 sites, should be managed more strictly than has been the case in recent decades, with maerl high-up on the conservation agenda. It is welcome that the French Ministry of the Environment has initiated a Natura 2000 monitoring programme but present funds are inadequate for assessment of even the largest Breton beds. It is imperative that conservation authorities inform stakeholders and government departments of the biological and economic importance of maerl conservation in Brittany. We hope this can be achieved through increased publicity for maerl grounds both in the scientific community (for example via this volume) and amongst the public at large.

\section{ACKNOWLEDGEMENTS}

We would like to thank Iwan Le Berre for producing the map together with Frédéric Bioret, Laurent Chauvaud, Gérard Thouzeau, Alphonse Tram and Geoff Moore for valuable feedback on the manuscript. This work was partly funded by the European Commission (CFP Study Project 90/018) and a Royal Society Research Fellowship to JH-S. Radiocarbon dating was funded by a NERC grant held jointly with Christine Maggs of Queen's University Belfast. This study neither reflects the views of the European Commission nor its future policy in this area.

\section{REFERENCES}

Augris C, Berthou P. 1986. Etude d'un site d'exploitation de maerl au nord des iles de Glenan. IFREMER Internal Report, $29 \mathrm{pp}$.

Augris C, Berthou P. 1990. Les gisements de maerl en bretagne. IFREMER Internal Report, 52 pages.

Bellan-Santini D, Lacaze JC, Poizat C. 1994. Les biocénoses marines et littorales de Méditerranée: synthèse, menaces et perspectives, Museum National d'Histoire Naturelle, Paris, 246 pp.

Berthois L, Guilcher A. 1959. Les bancs de St marc et du Moulin-Blanc (Rade de Brest). Remarques sur la sédimentation du maerl (Lithothamnium calcareum). Cahiers Océanographiques 11: 13-23.

BIOMAERL. 1999. Final Report, BIOMAERL project (Coordinator: P.G.Moore, University Marine Biological Station, Millport, Scotland), EC Contract No.MAS3-CT95-0020, (in 2 vols), 1: 1-541, 2: 542-973 pp + Appendix.

BIOMAERL Team. 2003. Conservation and management of NE Atlantic and Mediterranean maerl beds. Aquatic Conservation: Marine and Freshwater Ecosystems 13: S65-S76.

Bioret F, Malengrau D. 1989. Le narcisse des Glénan, de la protection à la gestion. Pen Ar Bed 132: 10-18.

Birkett DA, Maggs C, Dring MJ. 1998. "Maerl": an overview of dynamic and sensitivity characterisics for conservation management of marine SACs. The Scottish Association for Marine Science, UK Marine Special Areas of Conservation Project, 116 pp.

Blunden G, Farham WF, Jephson N, Fenn RH, Plunkett BA. 1977. The composition of maerl from the Glenan Islands of Southern Brittany. Botanica Marina 20: 121-125.

Briand X. 1989. Le Lithothamne: tradition d'hier et agrochimie de demain. Oceanis 15: 693-739.

Boillot G. 1964. Géologie de la Manche occidentale - fonds rocheux, dépots quaternaires, sédiments actuels. Annales de l'institut Océanographique, Paris 42: 1-220.

Cabioch J. 1966. Contribution à l'étude morphologique, anatomique et systématique de deux Mélobésiées: Lithothamnium calcareum (Pallas) Areschoug et Lithothamnium corallioides Crouan. Botanica Marina 9: 33-53. 
Cabioch J. 1969. Les fonds de maërl de la baie de Morlaix et leur peuplement végétal. Cahiers de Biologie Marine 10: 139-161.

Cabioch J. 1970. Le maërl des côtes de Bretagne et le problème de sa survie. Penn ar Bed 7: 421-429.

Cabioch L. 1968. Contribution à la connaissance des peuplements benthiques de la Manche occidentale. Cahiers de Biologie Marine 9: 493-720.

Chauvaud L, Jean F, Ragueneau O, Thouzeau G. 2000. Long term variation of the Bay of Brest: benthic-pelagic coupling revisited. Marine Ecology Progress Series 200: 35-48.

Coum A. 1979. La population de crépidules Crepidula fornicata (L) en rade de Brest: écologie et dynamique. Thèse de doctorat $3^{e}$ cycle, Université de Bretagne Occidentale, Brest $176 \mathrm{pp}$.

Dauvin JC (ed.). 1997. Les biocénoses marines et littorales francaises des côtes Atlantique, Manche et mer du Nord, synthèse, menaces et perspectives. Museum National d'Histoire-Naturelle, Paris 376 pp.

De Grave S, Whitaker A. 1999. Benthic community re-adjustment following dredging of a muddy-maerl matrix. Marine Pollution Bulletin 38: 102-108.

De Montaudouin X, Audemard C, Labourg PJ. 1999. Does the slipper limpet (Crepidula fornicata L.) impair oyster growth and zoobenthos biodiversity? A revisited hypothesis. Journal of Experimental Marine Biology and Ecology 235: $105-124$.

Drake P, Arias AM. 1997. The effect of aquaculture practices on the benthic macroinvertebrate community of a lagoon system in the Bay of Cadiz (Southwestern Spain). Estuaries 20: 677-688.

French Government, Ministry of Environment Website. 2001. Accessed March 2001: http://natura2000.environnement.gouv.fr/regions/REGFR52.html

Gautier M. 1971. Le maerl sur le littoral de la Bretagne. Cahiers Océanographiques 23: 171-191.

Glémarec M. 1969. Les peuplements benthiques du plateau continental Nord-gascogne. Thèse de Doctorat d'Etat, Brest 169 pp.

Grall J, Glémarec M. 1997a. Biodiversité des fonds de maerl en Bretagne: approche fonctionnelle et impacts anthropogéniques. Vie et Milieu 47: 339-349.

Grall J, Glémarec M. 1997b. Using biotic indices to estimate macrobenthic community perturbations in the Bay of Brest. Estuarine, Coastal and Shelf Science 44: 43-53.

Gray JS. 1992. Eutrophication in the sea. In Colombo G, Ferrari I, Ceccherelli VU and Rossi R (eds). Proceedings of the 25th European Marine Biology Symposium, Olsen and Olsen, Fredendsbog, 3-15.

Hall-Spencer JM, Moore PG. 2000. Scallop dredging has profound, long-term impacts on maerl habitats. ICES Journal of Marine Science 57: 1407-1415.

Hall-Spencer JM, Grall J, Moore PG, Atkinson RJA. 2003. Bivalve fishing and maerl bed conservation in France and the UK - retrospect and prospect. Aquatic Conservation: Marine and Freshwater Ecosystems 13: S33-S41.

Hamel G, Lemoine M. 1953. Corallinacées de France et d'Afrique du Nord. Archives du Museum National D'Histoire Naturelle 7: 15-136.

Hamon D, Blanchard M. 1994. Etat de la proliferation de la crépidule (Crepidula fornicata) en baie de Saint-Brieuc. Rapport interne IFREMER N ${ }^{\circ}$ 94.014.

Hinschberger F. 1968. Carte sédimentologique sous-marine des côtes de France au 1/100 000. IGN editions.

Huet M, Paulet YM, Glémarec M. 1995. Tributyltin (TBT) pollution in the coastal waters of west Brittany as indicated by imposex in Nucella lapillus. Marine Environmental Research 41: 157-167.

Ifremer Web site 2001. Accessed April 2001. http://www.ifremer.fr/delec/bb/crepidul.htm

Jacquotte R. 1962. Etude des fonds de maërl de Méditerranée. Recueils des travaux de la Station marine d'Endoume 26: $141-235$.

Judas A. 1998. Impact écologique de l'élevage de salmonidés à Camaret (finistère). Rapport contrat Elsamer SAl Ecosystèmes, UBO, Brest, 26 pp.

Lemoine P. 1910. Répartition et mode de vie du maërl (Lithothamnium calcareum) aux environs de Concarneau (Finistère). Annales de l'Institut Océanographique, Paris 1: 1-29.

Patris T, Lefebvre M, Troadec L, Laplanche A. 1995. Pollution chimique et bactérienne dans les eaux de ruissellement pluvial sur le bassin versant du Stang Alar. Ingenieries CEMAGREF, hors series, 51-58.

Paturel G. 1898. Composition chimique des sables calcaires du finistère. Publication du Laboratoire Agricole Départemental, $31 \mathrm{pp}$.

Pearson TH, Rosenberg R. 1978. Macrobenthic successions in relation to organic enrichment and pollution of the marine environment. Oceanography and Marine Biology: an Annual Review 16: 229-311.

Pinot JP. 1974. Le pré-contient Breton entre Penmarc'h, Belle-Ile et l'escarpement continental. Thèse de Doctorat d'Etat, Brest, 256 pp.

Retière C. 1979. Contribution à la connaissance des peuplements benthiques du golfe Normanno-Breton. Thèse de Doctorat d'Etat, Rennes, 421 pp. 
Thouzeau G. 1989. Determinisme du pré-recrutement de Pecten maximus (L.) en baie de Saint-Brieuc. Thèse de $3^{e}$ cycle, Brest, 545 pp.

Thouzeau G, Chauvaud L, Grall J, Guérin L. 2000. Rôle des intertactions biotiques sur le devenir du pré-recrutement et la croissance de Pecten maximus (L.) en rade de Brest. Comptes rendus de l'Académie des Sciences de Paris 323: 815-825.

Weston DP. 1990. Quantitative examination of macrobenthic community changes along an organic enrichment gradient. Marine Ecology Progress Series 61: 233-244. 